\title{
Building a patient blood management program in a large-volume tertiary hospital setting: Problems and solutions
}

\author{
Serdar Günaydın, Serdar ; Spahn, Donat R
}

\begin{abstract}
Successful implementation of a patient blood management program necessitates the collaboration of a strong organization and a multidisciplinary approach. We organized a meeting with broad participation in our center to establish a consensus for implementation of a specific patient blood management program. International and domestic experiences were shared, the importance of coordination and execution of different pillars in patient blood management were discussed, and the problems about the blood transfusion system were also investigated with the proposal for solutions. The data obtained from this meeting are presented to be a guide for similar large-volume tertiary hospitals for integration of a patient blood management protocol.
\end{abstract}

DOI: https://doi.org/10.5606/tgkdc.dergisi.2020.19701

Posted at the Zurich Open Repository and Archive, University of Zurich

ZORA URL: https://doi.org/10.5167/uzh-198421

Journal Article

Published Version

Originally published at:

Serdar Günaydın, Serdar; Spahn, Donat R (2020). Building a patient blood management program in a large-volume tertiary hospital setting: Problems and solutions. Turk Gogus Kalp Damar Cerrahisi Dergisi, 28(3):560-569.

DOI: https://doi.org/10.5606/tgkdc.dergisi.2020.19701 
Review / Derleme

\title{
Building a patient blood management program in a large-volume tertiary hospital setting: Problems and solutions
}

\author{
Büyük ölçekli hastane düzeninde hasta kan yönetimi programının oluşturulmasl: Sorunlar ve çözümleri
}

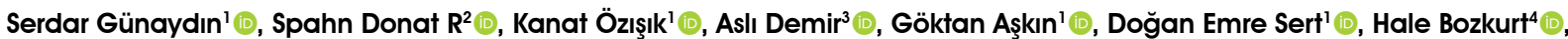

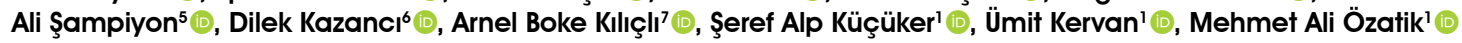 \\ Institution where the research was done: \\ Ankara City Hospital, Ankara, Turkey \\ Author Affiliations: \\ 'Department of Cardiovascular Surgery, Ankara City Hospital, Ankara, Turkey \\ 2Institute of Anesthesiology, University and University Hospital Zurich, Zurich, Switzerland \\ ${ }^{3}$ Department of Anesthesiology and Reanimation, Ankara City Hospital, Ankara, Turkey \\ 4Blood Bank, Ankara City Hospital, Ankara, Turkey \\ ${ }^{5}$ Cardiovascular Perfusion Services, Ankara City Hospital, Ankara, Turkey \\ oIntensive Care Unit, Ankara City Hospital, Ankara, Turkey \\ ${ }^{7}$ Department of Health Care Services, Nursing Unit, Ankara City Hospital, Ankara, Turkey
}

\begin{abstract}
Successful implementation of a patient blood management program necessitates the collaboration of a strong organization and a multidisciplinary approach. We organized a meeting with broad participation in our center to establish a consensus for implementation of a specific patient blood management program. International and domestic experiences were shared, the importance of coordination and execution of different pillars in patient blood management were discussed, and the problems about the blood transfusion system were also investigated with the proposal for solutions. The data obtained from this meeting are presented to be a guide for similar large-volume tertiary hospitals for integration of a patient blood management protocol.

Keywords: Anemia-iron deficiency; blood preservation; blood transfusion; hemorrhage.
\end{abstract}

The World Health Organization (WHO) described the patient blood management (PBM) in the early 2000s, which was made effective in the Netherlands for the first time. In 2008, Australia was the first country which made it compulsory nationwide..$^{[1-3]}$ The United States, in 2007, published a guideline on bleeding and blood management before and after

\section{$\ddot{o z}$}

Hasta kan yönetimi programının başarılı bir şekilde uygulanması, güçlü bir organizasyon iş birliği ve multidisipliner bir yaklaşım gerektirir. Merkezimizde spesifik bir hasta kan yönetimi programının uygulanmasına yönelik bir konsensüs oluşturmak amacıyla geniş katılımlı bir toplantı düzenlendi. Uluslararası ve yerel deneyimler paylaşıldı, hasta kan yönetiminde farklı ayakların koordinasyonu ve yürütülmesinin önemi tartışıldı ve kan nakli sistemine ilişkin sorunlar çözüm önerileri ile birlikte ele alındı. Bu toplantıdan elde edilen veriler, hasta kan yönetim protokolü entegrasyonu açısından benzer büyük ölçekli üçüncü basamak hastaneler için de rehber olabilmesi amacıyla paylaşıldı.

Anahtar sözcükler: Anemi-demir eksikliği; kan koruma; kan nakli; kanama.

cardiac surgery. ${ }^{[4]}$ The criticism and suggestions were considered for four years and were used to reform the guideline in $2011 .^{[5]}$ The European PBM guideline was published in $2017{ }^{[6]}$ and the Turkish guideline was published in 2019. ${ }^{[7]}$ Numerous studies conducted in these countries endorsed 30 to $40 \%$ reduction in the number of blood transfusions, significant resource

Received: March 24, 2020 Accepted: April 30, 2020 Published online: July 28, 2020

Correspondence: Serdar Günaydın, MD. Ankara Şehir Hastanesi Kalp ve Damar Cerrahisi Kliniği, 06800 Çankaya, Ankara, Türkiye.

Tel: +90 536 - 3896521 e-mail: serdarkvc@gmail.com

Cite this article as:

Günaydın S, Donat R S, Özıșık K, Demir A, Așkın G, Sert DE, et al. Building a patient blood management program in a large-volume tertiary hospital setting: Problems and solutions. Turk Gogus Kalp Dama 2020;28(3):560-569 
savings, and a significant reduction in morbidity and mortality of patients.

The PBM is a three-pillar strategy to cure preoperative anemia and iron deficiency (intravenous [IV] iron + erythropoietin [EPO] + vitamin B12 + folic acid), reduce preoperative red blood cell (RBC) loss by an improved surgical technique, cell salvage, and re-transfusion, acute normovolemic hemodilution, coagulopathy management (anti-fibrinolytics, fibrinogen, Factor XIII, prothrombin complex concentrate $[\mathrm{PCC}]$, low central venous pressure, no hypertension, normothermia), and optimize anemia management (tolerate low hemoglobin values, IV iron + EPO postoperatively, increased fraction of inspired oxygen $\left.\left[\mathrm{FiO}_{2}\right]\right)^{[8-13]}$

In this review, we aimed to share previous experiences and indicate current problems with solutions which would ensure the implementation of a PBM protocol in our hospital that can be also a guide for similar large-volume tertiary hospitals.

\section{SUCCESSFUL IMPLEMENTATION STORIES: INTERNATIONAL}

\section{University Hospital of Zurich PBM Program}

The University Hospital of Zurich (USZ) aimed to achieve the best possible surgical patient outcome (lowest mortality, no organ dysfunction, no lung injury, no renal impairment, no stroke, no myocardial infarction, minimal infection rate, minimal thromboembolic adverse events, minimal length of hospital stay, least amount of blood product transfusions, minimal costs) and adopted the strategies of PBM to attain this target.
Key steps in the implementation of PBM included the development of hospital-wide guidelines, creating a commission for the responsible use of blood products, achieving general ownership at all disciplines, monitoring guideline adherence, and collecting data to evaluate the success rate. Firstly, the anesthesiology department, in collaboration with the hematology department, developed evidencebased transfusion and anemia management guidelines (Tables 1 and 2). Eight specialties were defined to use these guidelines: cardiac surgery, trauma, transplantation, obstetrics, neurosurgery, burn unit, intensive care unit (ICU), and plastic surgery. Patients with an RBC transfusion rate of $>10 \%$ and an expected blood loss of $>500 \mathrm{~mL}$ were included as the focus group identified by the workgroup of USZ. The PBM program organization is listed in Table 3.

The PBM was put into practice in USZ about 10 years ago, and its success was demonstrated in many studies. ${ }^{[14,15]}$

\section{SUCCESSFUL IMPLEMENTATION STORIES: NATIONAL}

\section{Numune Training and Research Hospital}

The cardiovascular surgery clinic of Ankara Numune Training and Research Hospital in 2016 was one of the pioneers in launching the first applications of PBM in Turkey (Table 4). Thus, a two-step project was implemented: firstly, initiating a PBM program in the cardiovascular surgery clinic and subsequently, spreading out the program to the entire hospital after accomplishing successful outcomes.

Table 1. University Hospital of Zurich Guideline-Hemoglobin thresholds for transfusion

\begin{tabular}{ll}
\hline Healthy parturient & $\mathrm{Hb}<60 \mathrm{~g} / \mathrm{L}$ \\
\hline Patients without significant comorbidities & $\mathrm{Hb}<70 \mathrm{~g} / \mathrm{L}$ \\
Patients with & \\
- $\mathrm{SaO}_{2}<90 \%$ despite optimized ventilation & $\mathrm{Hb}<80 \mathrm{~g} / \mathrm{L}$ \\
- Severe traumatic brain injury & \\
- Free flaps & \\
- Severe $(>70 \%)$ carotid stenosis & $\mathrm{Hb}<90 \mathrm{~g} / \mathrm{L}$ \\
Patients with unstable coronary artery disease & $\mathrm{Hb} \geq 90 \mathrm{~g} / \mathrm{L}$ \\
No indication & $\mathrm{Hb}<100 \mathrm{~g} / \mathrm{L}$ unexpectedly \\
Surgery stopped $\rightarrow$ evaluation & $\mathrm{Hb} 100-129 \mathrm{~g} / \mathrm{L}$ or iron deficiency at Hb $\geq 130 \mathrm{~g} / \mathrm{L}$ \\
Pre-treatment according to Table 2 & $\mathrm{Hb} \geq 130 \mathrm{~g} / \mathrm{L}$ men and women and no iron deficiency \\
Patients of the focus group can be operated if $\rightarrow$ & $($ Ferritin $\geq 100 \mu \mathrm{g} / \mathrm{L}$ and TSAT $\geq 20 \%)$ \\
\hline
\end{tabular}

SaO2: Oxygen saturation; Hb: Hemoglobin; TSAT: Transferrin saturation. 
Table 2. University Hospital of Zurich Guideline-Preoperative treatment of anemia

\begin{tabular}{|c|c|c|}
\hline Hemoglobin & $\begin{array}{l}\text { Iron parameters } \\
\text { Kidney function } \\
\text { (Low grade) infection }\end{array}$ & Treatment \\
\hline $\begin{array}{l}\text { Hemoglobin }<130 \mathrm{~g} / \mathrm{L} \\
\text { "ID Anemia"* }\end{array}$ & $\begin{array}{l}\text { Ferritin }<100 \mu \mathrm{g} / \mathrm{L} \text { or } \\
\text { TSAT }<20 \% \\
\text { CCL } \geq 50 \mathrm{~mL} / \mathrm{min}\end{array}$ & $\begin{array}{l}20 \mathrm{mg} / \mathrm{kg} \text { BW iron carboxymaltose (IV) } 30 \mathrm{~min}+1 \mathrm{mg} \\
\text { vitamin B12 (sc) }+5 \mathrm{mg} \text { folic acid (po) }\end{array}$ \\
\hline $\begin{array}{l}\text { Hemoglobin }<130 \mathrm{~g} / \mathrm{L} \\
\text { "Renal anemia" }\end{array}$ & $\begin{array}{l}\text { Ferritin } \geq 100 \mu \mathrm{g} / \mathrm{L} \text { and } \\
\text { TSAT } \geq 20 \% \\
\text { CCL }<50 \mathrm{~mL} / \mathrm{min}\end{array}$ & $\begin{array}{l}\text { Epoetin alpha } 600 \mathrm{U} / \mathrm{kg} \mathrm{BW} \\
20 \mathrm{mg} / \mathrm{kg} \text { BW iron carboxymaltose (IV) } 30 \mathrm{~min}+1 \mathrm{mg} \\
\text { vitamin B12 (sc) }+5 \mathrm{mg} \text { folic acid (po) }\end{array}$ \\
\hline $\begin{array}{l}\text { Hemoglobin }<130 \mathrm{~g} / \mathrm{L} \\
\text { "Anemia of chronic disease" }\end{array}$ & $\begin{array}{l}\text { Ferritin } \geq 100 \mu \mathrm{g} / \mathrm{L} \text { and } \\
\mathrm{TSAT} \geq 20 \% \\
\mathrm{CRP}>5 \mathrm{mg} / \mathrm{L}\end{array}$ & $\begin{array}{l}\text { Epoetin alpha } 600 \mathrm{U} / \mathrm{kg} \mathrm{BW} \\
20 \mathrm{mg} / \mathrm{kg} \mathrm{BW} \text { iron carboxymaltose (IV) } 30 \mathrm{~min}+1 \mathrm{mg} \\
\text { vitamin B12 (sc) }+5 \mathrm{mg} \text { folic acid (po) }\end{array}$ \\
\hline $\begin{array}{l}\text { Hemoglobin } \geq 130 \mathrm{~g} / \mathrm{L} \\
\text { "Isolated ID" }\end{array}$ & $\begin{array}{l}\text { Ferritin }<100 \mu \mathrm{g} / \mathrm{L} \text { or } \\
\text { TSAT }<20 \%\end{array}$ & $20 \mathrm{mg} / \mathrm{kg}$ BW iron carboxymaltose (IV) $30 \mathrm{~min}$ \\
\hline
\end{tabular}

*Surgery in $<5$ days $\rightarrow$ additionally Epoetin alpha $600 \mathrm{U} / \mathrm{kg}$ BW; TSAT: Transferrin saturation; CCL: Creatinine clearance; IV: Intravenous; po: Per oral; sc: Subcutaneous; BW: Body weight; CRP: C-reactive protein; ID: Iron deficiency.

Staff training, transfusion monitoring, IV fluid restriction, preoperative anemia treatment (IV iron carboxymaltose),revision and adaptation of international guidelines, and cooperation with cardiology were the parts of the preoperative phase. ${ }^{[16]}$ The preoperative phase included goal-directed coagulation (impaired platelet function, surgical bleeding, etc.), goal-directed perfusion (low blood pressure or anemia may not be indicative of blood transfusion every time, what is important is the oxygen that penetrates the tissues), minimally invasive surgery, routine tranexamic acid administration, cerebral/somatic oximetry, minimally invasive extracorporeal circulation circuits, microplegia, retrograde autologous priming, vacuum-assisted venous drainage, ultrafiltration, cytokine adsorption, and recirculation of waste blood. The postoperative phase comprised of transfusion monitoring, IV fluid restriction, fibrinogen concentrate administration, and goal-directed coagulation tests.
A remarkable reduction in the use of blood and blood products after this PBM program was evident in the cardiovascular surgery clinic (Figure 1). A significant cost reduction was also achieved by implementing the PBM program. To accurately determine the cost of blood in this population, the activity-based costing (ABC) model was used as described by Shander et al. ${ }^{[17]}$ The cost of approximately 42 triple coronary artery bypass surgeries was saved. Hospital records documented early extubation of patients accompanied by reduction of bleeding rates, shortening of the length of stay in hospital and ICU, and reduced mortality rate. Therefore, PBM was also successful in improving clinical outcomes. In the light of these data, Numune Hospital was entitled to 2018: JCI Patient Blood Management Certification.

Successful consequences obtained in the first step motivated the dissemination of the project in all

\section{Table 3. University Hospital of Zurich-Patient blood management program organization}

- Nominating a patient blood manager to educate representatives of surgical disciplines and making them adopt patient blood management over time

- Creating a commission for the responsible use of blood products (NOT traditional hemovigilance) as mandated by the Board of Directors via Medical Director and executed by both chairmen of Anesthesiology and Hematology

- Developing hospital-wide transfusion and coagulation management guidelines (for some "special" patients modifications are possible but should be strictly evidence-based)

- Establishing an intelligent blood ordering system

- Developing a monitoring and feedback system to collect data and assure the success of the program

- Developing an information technology program for early testing of focus patients (red blood cell transfusion rate $\geq 10 \%$ or expected blood loss $\geq 500 \mathrm{~mL}$ ) for anemia and iron deficiency

- Giving early treatment aiming at a hemoglobin $\geq 130 \mathrm{~g} / \mathrm{L}$ and no iron deficiency (ferritin $\geq 100 \mathrm{ng} / \mathrm{mL}$ and transferrin saturation $[\mathrm{TSAT}] \geq 20 \%$ ) 
Table 4. 2016 data of Ankara Numune Training and Research Hospital

\begin{tabular}{ll}
\hline Ankara Numune Training and Research Hospital & \\
\hline Total number of beds & 1,140 \\
Annual number of outpatient visits & $1,768,649$ \\
Annual number of operations & 55,469 \\
Annual number of blood use & $34,881 \mathrm{U}$ \\
Cardiovascular Surgery Clinic & \\
Annual number of outpatient visits & 34,445 \\
Annual number of operations & 1,318 \\
Annual number of blood use & $2,829 \mathrm{U}$ \\
(All operations by the department of & - Whole blood 140 U \\
cardiovascular surgery including emergency) & : Erythrocyte suspension $855 \mathrm{U}$ \\
& - Presh frozen plasma $1667 \mathrm{U}$ \\
\end{tabular}

surgical clinics. Objectives of the program included determining the current situation, determining the problems in blood use, constituting a team of surgical branches, and holding meetings to form a strategic plan with the purpose of reducing blood use in the hospital by $50 \%$ in the 2018 to 2021 period. Approximately 35,000 units of total blood and blood products were utilized for about 55,000 operations at Numune Hospital in 2017. Figure 2 illustrates the distribution in some prominent branches.

The in-depth investigation highlighted the wastage of many of the unused blood products, which incurred a high cost equivalent to 16 triple coronary artery bypass surgeries (Table 5). As depicted in Table 6, the reasons for the destruction of blood and blood products were quite striking.

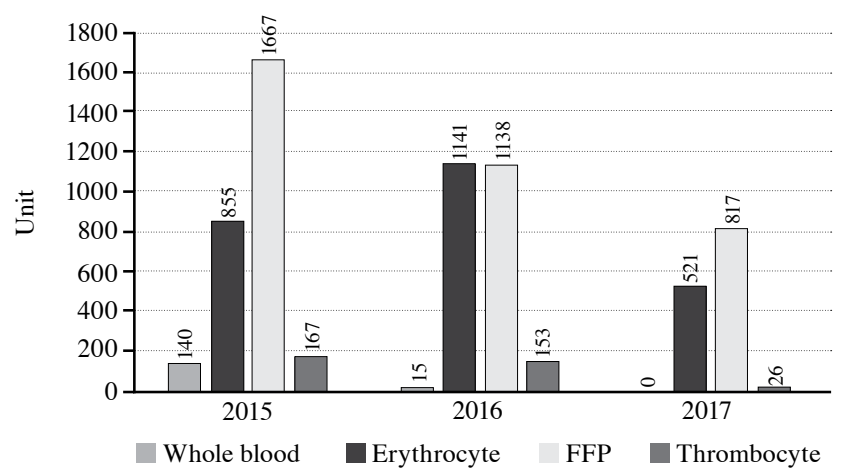

Figure 1. Ankara Numune Training and Research Hospital-the usage of blood and blood products in the cardiovascular surgery clinic by years (2015-2017 data).

FFP: Fresh frozen plasma.
In 2018, hospital-wide blood and blood product usage dropped to 29,500 units, approximately. Therefore, a reduction in blood and blood product usage by $3 \%$ could be achieved in one year by conducting multidisciplinary scientific meetings and initiatives in surgical clinics of Numune Training and Research Hospital (Figure 3).

The data obtained from the Numune Hospital were published in various journals and presented at international congresses. ${ }^{[18-22]}$ Subsequently, international training programs were launched in Turkey. The EuroAsia Heart Foundation decided to organize PBM Schools in Turkey, and the first meeting entitled Interdisciplinary Meeting on Bleeding Management in (Cardiac) Surgery and Obstetrics was held with 55 participants from 11 countries in Izmir in April 2019.

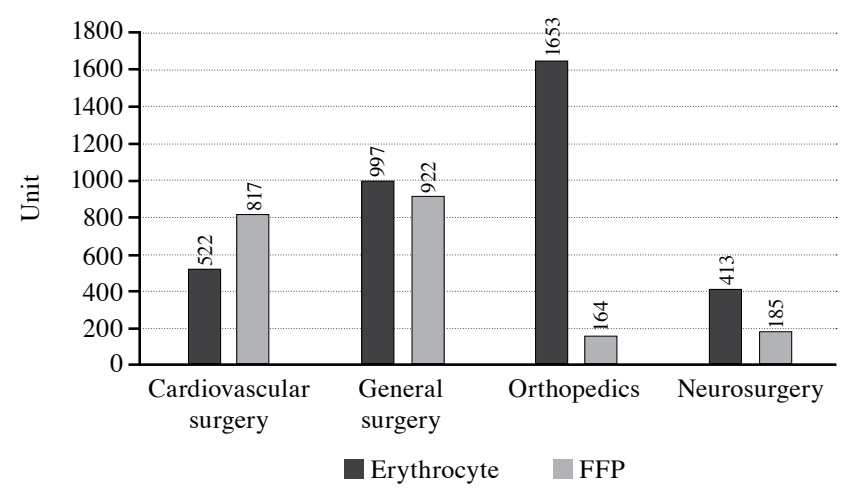

Figure 2. Ankara Numune Training and Research Hospital-the usage of blood products by branches (2017 data).

FFP: Fresh frozen plasma. 
Table 5. Ankara Numune Training and Research Hospital - Used and destroyed blood products

\begin{tabular}{|c|c|c|c|c|}
\hline & \multicolumn{2}{|c|}{2016} & \multicolumn{2}{|c|}{2017 (January-September) } \\
\hline & Used (U) & Destroyed (U) & Used (U) & Destroyed (U) \\
\hline \multirow{2}{*}{ Erythrocyte suspension } & 13,805 & 329 & 9,527 & 188 \\
\hline & \multicolumn{2}{|c|}{ Random } & \multicolumn{2}{|c|}{ Random } \\
\hline \multirow{3}{*}{ Platelet suspension } & 2,476 & 89 & - & - \\
\hline & \multicolumn{2}{|c|}{ Pooled platelet (4 U) } & \multicolumn{2}{|c|}{ Pooled platelet (4 U) } \\
\hline & 1,931 & 43 & 1,720 & 59 \\
\hline Fresh frozen plasma & 12,964 & 330 & 7,768 & 192 \\
\hline Apheresis platelet suspension & 816 & 21 & 316 & 7 \\
\hline Whole blood & 17 & 2 & - & - \\
\hline Cryoprecipitate & 235 & - & 425 & 5 \\
\hline
\end{tabular}

\section{Consensus Meeting on PBM}

The second stage of Numune Hospital's PBM program was decided to be continued in a larger scale hospital, which was established by the transportation of Ankara's largest state hospitals and put into service in December 2018. The city hospital comprises of 3,804 hospital beds, 735 outpatient

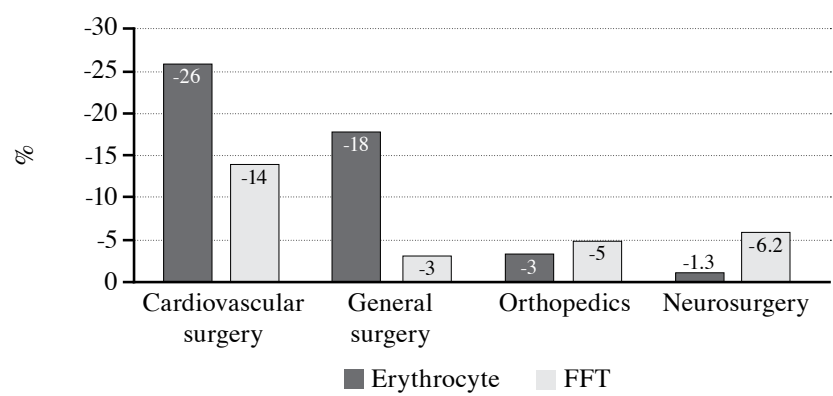

Figure 3. Ankara Numune Training and Research Hospital-reduction in blood products usage in one year (2018 data).

FFP: Fresh frozen plasma. clinics, and 128 operating theaters. The PBM has become one of the most important targets in the city hospital. The main objective of PBM implementation is to portray a good example for other hospitals in Turkey. The data gathered from the City Hospital on blood product usage and destruction are detailed in Tables 7 and 8 .

A strong organization, coupled with a multidisciplinary approach, is a prerequisite to cope with similar challenges during the implementation of PBM program in City Hospital.

Aiming at kick-off building a multidisciplinary PBM program in this extremely large hospital setting, a consensus meeting was organized to provide a platform where all components may come together to fix problems, discuss, and propose solutions. Over 150 participants in the meeting included members from the departments of anesthesiology, surgery, transplantation, ICU, perfusion, blood bank, nursing, pharmacy, and Ministry of Health. Professor Donat Spahn from the University Hospital of Zurich, being

Table 6. Ankara Numune Training and Research Hospital-Reasons for the destruction of blood products

\begin{tabular}{lccc}
\hline $\begin{array}{l}\text { Erythrocyte suspension } \\
\text { (storage time: } 42 \text { days) }\end{array}$ & $\begin{array}{c}\text { Platelet suspension } \\
\text { (storage time: } 5 \text { days) }\end{array}$ & $\begin{array}{c}\text { FFP } \\
\text { (storage time: 2 years) }\end{array}$ & $\begin{array}{c}\text { Apheresis platelet suspension } \\
\text { (storage time: 5 days) }\end{array}$ \\
\hline $\begin{array}{l}\text { Passing the expiration date } \\
94.15 \%\end{array}$ & $\begin{array}{c}\text { Passing the expiration date } \\
\text { Late returning from the services }\end{array}$ & $\begin{array}{c}\text { Returning after thawing } \\
\text { 100\% }\end{array}$ & $\begin{array}{c}\text { Passing the expiration date } \\
\text { Product bag burst }\end{array}$ \\
5.85\% & & $67.71 \%$ & $100 \%$ \\
\hline
\end{tabular}

FFP: Fresh frozen plasma. 
Table 7. Ankara City Hospital Transfusion Center-used and destroyed blood products (February 2019-July 2019)

\begin{tabular}{|c|c|c|c|c|c|}
\hline & \multicolumn{2}{|c|}{ Used (\%) } & \multicolumn{2}{|c|}{ Destroyed (\%) } & \multirow{2}{*}{$\begin{array}{c}\text { Total } \\
\mathrm{n}\end{array}$} \\
\hline & $\mathrm{n}$ & $\%$ & $\mathrm{n}$ & $\%$ & \\
\hline Erythrocyte suspension & 12,847 & 96 & 467 & 4 & 13,314 \\
\hline Fresh frozen plasma & 8,517 & 95 & 413 & 5 & 8,930 \\
\hline Pooled platelet suspension & 1,532 & 89 & 184 & 11 & 1,716 \\
\hline Apheresis platelet suspension & 49 & 84 & 9 & 16 & 58 \\
\hline Cryoprecipitate & 1,158 & 94 & 71 & 6 & 1,229 \\
\hline Total & 24,103 & 95 & 1,144 & 5 & 25,247 \\
\hline
\end{tabular}

Table 8. Ankara City Hospital Transfusion Center-reasons for the destruction of blood products (February 2019July 2019)

\begin{tabular}{|c|c|c|c|c|c|c|c|}
\hline & \multicolumn{2}{|c|}{ Storage condition } & \multicolumn{2}{|c|}{ Expiration date } & \multicolumn{2}{|c|}{ Perforated bag } & \multirow{2}{*}{$\begin{array}{c}\text { Total } \\
\mathrm{n}\end{array}$} \\
\hline & $\mathrm{n}$ & $\%$ & $\mathrm{n}$ & $\%$ & $\mathrm{n}$ & $\%$ & \\
\hline Erythrocyte suspension & 127 & 27 & 333 & 71 & 7 & 2 & 467 \\
\hline Fresh frozen plasma & 249 & 60 & - & - & 164 & 40 & 413 \\
\hline Pooled platelet suspension & 4 & 2 & 178 & 97 & 2 & 1 & 184 \\
\hline Apheresis platelet suspension & - & - & 9 & 100 & - & - & 9 \\
\hline Cryoprecipitate & 62 & 87 & 2 & 3 & 7 & 10 & 71 \\
\hline Total & 442 & 37 & 522 & 47 & 180 & 16 & 1144 \\
\hline
\end{tabular}

\section{1) Anesthesiology and Reanimation}

Problems
Inadequate diagnosis and treatment of preoperative anemia

Inappropriate, irrational, traditional blood and blood product transfusion

Insufficient information in indications for the use of cryoprecipitate, fibrinogen concentrate, antifibrinolytic, and prothrombin complex concentrate

Inappropriate storage of blood in the clinics

Lack of well-defined protocols for various critical clinical situations (i.e., massive transfusion protocol, critical cardiac/pulmonary/renal disease protocols, critical transfusion thresholds, and reversal protocols in antiplatelet/ anticoagulant use)

\section{Solutions}

Preoperative diagnosis and treatment of anemia, stabilization of comorbidities, physical optimization, deferring the operation if necessary, determining the patient's bleeding risk, and scheduling surgery accordingly ${ }^{[23]}$

Management of anesthesia according to patient blood management, usage of tranexamic acid, retrograde autologous priming and autologous donation in the pump, providing qualified surgery and meticulous hemostasis, prevention of hypothermia after cardiopulmonary bypass, and optimization of cardiopulmonary functions ${ }^{[24]}$

Ensuring the accuracy of the records of transfused patients by eradicating inappropriate blood stores

Establishment of a local blood center unit in the common aisle of operating theaters and elimination of problems related to transport distances and staff securing the cold chain of blood products

Multidisciplinary preparation of required protocols in accordance with the patient profile and defining the transfusion practices clearly and precisely in the hospital protocol 
one of the leaders in the implementation of the PBM program, was invited and acted as a consultant.

In this multidisciplinary meeting, international and domestic experiences were shared, the importance of coordination and execution of different pillars in PBM was discussed, and the problems of the blood transfusion system were also explored with a proposal for solutions. Based on these data, it was aimed to develop a standard protocol for PBM which could be used as a guide by similar large-volume tertiary hospitals. ${ }^{[23,24]}$
There is not any purpose of comparison of any previous data with each other and/or with current situation. The geographic and background conditions of each instant are completely different. The main idea is to present different PBM protocols in various hospital settings.

\section{Synopsis of Problems/Solutions}

The following problems and proposals for the solutions were documented, discussed with managers, and a final consensus report was submitted for the hospital directorate.

\section{2) Blood Transfusion Center}

\begin{tabular}{ll}
\hline Problems & Solutions \\
\hline $\begin{array}{l}\text { New installation of the system/integration, automation } \\
\text { problems }\end{array}$ & $\begin{array}{l}\text { Training should continue uninterruptedly (nurse, physician, } \\
\text { staff) } \\
\text { Distance between units } \\
\text { Inexperienced allied health personnel }\end{array}$ \\
$\begin{array}{l}\text { Rapid and safe transportation should be provided } \\
\text { The opinions of experienced individuals working in the field } \\
\text { should be acknowledged }\end{array}$ \\
Habitual malpractice & $\begin{array}{l}\text { Blood and blood products must be preserved to the } \\
\text { maximum extent, and their destruction should be strictly } \\
\text { prohibited, except for medical reasons }\end{array}$ \\
\hline
\end{tabular}

\section{3) Nursing Services}

\begin{tabular}{ll}
\hline Problems & Solutions \\
\hline $\begin{array}{l}\text { Determination of blood type and cross-match (differently } \\
\text { written blood type on the file and system, reaffirmation of } \\
\text { blood types many times, sometimes labeling errors) }\end{array}$ & $\begin{array}{l}\text { Use of blood barcode readers in clinics and an identity- } \\
\text { check to be used for labeling the blood sample tube before } \\
\text { leaving the bedside }\end{array}$ \\
$\begin{array}{l}\text { Calling the blood center from the clinic to verify if the } \\
\text { blood for cross-match has reached (waiting time on the } \\
\text { phone, calling the blood center many times to check the } \\
\text { cross-match) }\end{array}$ & $\begin{array}{l}\text { Establishing an electronic blood monitoring system } \\
\begin{array}{l}\text { Differences in the time of receiving the blood transfusion } \\
\text { consent form }\end{array}\end{array}$ \\
$\begin{array}{l}\text { Mode of transportation used to deliver the blood to the clinic } \\
\text { Delivery of non-irradiated blood although irradiated blood } \\
\text { was requested and return of blood for processing }\end{array}$ & $\begin{array}{l}\text { Rapid and safe transportation should be provided } \\
\text { Estimating compliance with hospital protocols/clinical } \\
\text { guidelines in practice }\end{array}$ \\
$\begin{array}{l}\text { Lack of pediatric blood bag } \\
\text { Different applications for transfusion tracking form } \\
\text { according to the clinics (sometimes writing patient } \\
\text { information manually, sometimes sticking barcode, } \\
\text { sometimes second copy labeling error) }\end{array}$ & $\begin{array}{l}\text { Use of simulation in blood transfusion training to ensure } \\
\text { patient safety }\end{array}$ \\
$\begin{array}{l}\text { Noprotocols of transfusion foremergency and extracorporeal } \\
\text { membrane oxygenation patients }\end{array}$ & $\begin{array}{l}\text { Proper education and training regarding clinical guidelines } \\
\text { provided to the health professionals on blood product } \\
\text { transfusion and patient blood management }\end{array}$ \\
\hline
\end{tabular}




\section{1) Anesthesiology and Reanimation}

\section{2) Blood Transfusion Center}

\section{3) Nursing Services}

The blood transfusion procedures of our hospital are prepared following the national guidelines, National Blood and Blood Components Preparation, Use and Quality Assurance Guideline-2016, ${ }^{[25]}$ and National Hemovigilance Guideline-2016. ${ }^{[26]}$ According to these blood transfusion procedures, monitoring, educating, reporting, analysis, and documentation of blood transfusion applications are the responsibilities of our hemovigilance nurses.

\section{4) Intensive care unit}

\section{5) Transplantation Services}

\section{6) Perfusion Services}

\section{Conclusion}

The liberal RBC transfusion approaches can effectively achieve restoration of hemoglobin concentrations toward non-anemic values; however,

\section{4) Intensive care unit}

\begin{tabular}{|c|c|}
\hline Problems & Solutions \\
\hline $\begin{array}{l}\text { Varying indications of transfusion in different intensive care } \\
\text { unit (ICU) units }\end{array}$ & Active use of guidelines in clinical practice \\
\hline $\begin{array}{l}\text { Problems in accessing the blood product (particularly in } \\
\text { emergencies) and transportation problems }\end{array}$ & Rapid and safe transportation \\
\hline Blood product storage problems & $\begin{array}{l}\text { Establishment of a local blood center unit in the common } \\
\text { aisle of ICUs and elimination of problems related to } \\
\text { transport distances and staff }\end{array}$ \\
\hline Lack of interdisciplinary communication & $\begin{array}{l}\text { Establishing a transfusion strategy in compliance with the } \\
\text { hospital conditions and employee profile }\end{array}$ \\
\hline Transfusion-related complications & $\begin{array}{l}\text { Collecting statistical data and feedbacks (i.e., percentages } \\
\text { blood product use, mortality, morbidity, length of stay in the } \\
\text { hospital, and ICU, mean pretransfusion values, and costs) }\end{array}$ \\
\hline
\end{tabular}

\section{5) Transplantation Services}

\section{Problems}

Late arrival of the blood products is the major problem.

Problems with the management of the hospital

Authority issues related to allied health personnel

Different indications with different physicians

\section{Solutions}

Rapid and safe delivery

Appointing the hospital as a blood donation center, providing viscoelastic testing and new oral anticoagulant antidotes to the hospital

Defining duties of the personnel in a guideline

Establishing a common diagnosis and treatment approach for the management of anemia

\section{6) Perfusion Services}

Problems
Varying perfusion protocols for different surgeons
Different approaches in different disciplines in the operating
room

No experience in novel extracorporeal technologies for avoiding perioperative bleeding in cardiovascular surgery

\section{Solutions}

Developing an institutional culture and determining common protocols

Being in contact with surgeons, anesthesiologists, and perfusionists avoiding interference of each other's applications

Ensuring the use of autotransfusion devices, mini-circuits, vacuum-assisted venous drainage, retrograde autologous priming and centrifugal pumps in every appropriate case 
transfusion of stored allogeneic RBCs does not correct the primary metabolic deficiencies associated with anemia, nor does it restore iron homeostasis. On the other hand, it has become a common practice to transfuse stable patients with low hemoglobin without symptoms of anemia. ${ }^{[27]}$

Despite the demonstrated benefits of PBM, several challenges limit the application of PBM guidelines into clinical practice worldwide, particularly due to the lack of knowledge, lack of interdisciplinary commitment, lack of resources, and general concerns. It should enable PBM's patient-centered approach to be delivered in a way that is also hospital centered and, therefore, compatible with each institution. The initial success achieved from the institution should impart further motivation and activities in the field of PBM. ${ }^{[28,29]}$

Pillars need to be adapted with respect to characteristics of the region and legislations available. For instance, there are specific reimbursement policies for IV iron therapy in Turkey. Also, limitations of the use of EPO and vitamin B12/folic acid by nephrologists may become a burden for cardiac surgeons to implement perioperative anemia correction. Successful PBM implementation involves structural changes, logistic reorganizations and leadership with psychological skills, a monitoring, and feedback program, and persistence. An individualized program must be established by the hospitals with the consensus of participants.

The Ankara City Hospital is the largest hospital in Turkey. Current practice with the use of more than 60,000 units of blood and blood products in one year necessitates the need for a PBM program.

We believe that this consensus report would accelerate the cooperation within disciplines and provoke more optimal results in the short-term. Furthermore, it is valuable as it represents a guide for similar large-volume hospital settings.

\section{Acknowledgement}

We thank to Figen Yavuz, MD (Turkiye Klinikleri) for her valuable assistance in the writing process of this review.

\section{Declaration of conflicting interests}

The authors declared no conflicts of interest with respect to the authorship and/or publication of this article.

\section{Funding}

The authors received no financial support for the research and/or authorship of this article.

\section{REFERENCES}

1. What is patient blood management (PBM)? Available at: http://www.sabm.org/ [Accessed: March 03, 2019].

2. Implementing the PBM guidelines. Available at: https://www. blood.gov.au/implementing-pbm [Accessed: March 03, 2019].

3. Patient blood management guidelines. Available at: https:// www.blood.gov.au/pbm-guidelines [Accessed: March 03, 2019].

4. Ferraris VA, Ferraris SP, Saha SP, Hessel EA 2nd, Haan $\mathrm{CK}$, Royston $\mathrm{BD}$, et al. Perioperative blood transfusion and blood conservation in cardiac surgery: The Society of Thoracic Surgeons and The Society of Cardiovascular Anesthesiologists clinical practice guideline. Ann Thorac Surg 2007;83:S27-86.

5. Ferraris VA, Brown JR, Despotis GJ, Hammon JW, Reece TB, Saha SP, et al. 2011 update to the Society of Thoracic Surgeons and the Society of Cardiovascular Anesthesiologists blood conservation clinical practice guidelines. Ann Thorac Surg 2011;91:944-82.

6. Pagano D, Milojevic M, Meesters MI, Benedetto U, Bolliger D, von Heymann C, et al. 2017 EACTS/EACTA Guidelines on patient blood management for adult cardiac surgery. Eur J Cardiothorac Surg 2018;53:79-111.

7. Ertugay S, Kudsioğlu T, Şen T; Patient Blood Management Study Group Members. Consensus Report on Patient Blood Management in Cardiac Surgery by Turkish Society of Cardiovascular Surgery (TSCVS), Turkish Society of Cardiology (TSC), and Society of Cardio-Vascular-Thoracic Anaesthesia and Intensive Care (SCTAIC). Turk Gogus Kalp Dama 2019;27:429-50.

8. Spahn DR, Moch H, Hofmann A, Isbister JP. Patient blood management: the pragmatic solution for the problems with blood transfusions. Anesthesiology 2008;109:951-3.

9. Farrugia A. Falsification or paradigm shift? Toward a revision of the common sense of transfusion. Transfusion 2011;51:216-24.

10. Spahn DR, Goodnough LT. Alternatives to blood transfusion. Lancet 2013;381:1855-65.

11. Muñoz M, Acheson AG, Auerbach M, Besser M, Habler O, Kehlet $\mathrm{H}$, et al. International consensus statement on the peri-operative management of anaemia and iron deficiency. Anaesthesia 2017;72:233-47.

12. Althoff FC, Neb H, Herrmann E, Trentino KM, Vernich L, Füllenbach C, et al. Multimodal Patient Blood Management Program Based on a Three-pillar Strategy: A Systematic Review and Meta-analysis. Ann Surg 2019;269:794-804.

13. Arıtürk C, Ozgen ZS, Kilercik M, Ulugöl H, Ökten EM, Aksu U, et al. Comparative effects of hemodilutional anemia and transfusion during cardiopulmonary bypass on acute kidney injury: a prospective randomized study. Heart Surg Forum 2015;18:E154-60.

14. Stein P, Kaserer A, Sprengel K, Wanner GA, Seifert $\mathrm{B}$, Theusinger OM, et al. Change of transfusion and treatment paradigm in major trauma patients. Anaesthesia 2017;72:1317-26.

15. Kaserer A, Rössler J, Braun J, Farokhzad F, Pape HC, Dutkowski P, et al. Impact of a Patient Blood Management 
monitoring and feedback programme on allogeneic blood transfusions and related costs. Anaesthesia 2019;74:1534-41.

16. Senay S, Toraman F, Karabulut H, Alhan C. Is it the patient or the physician who cannot tolerate anemia? A prospective analysis in 1854 non-transfused coronary artery surgery patients. Perfusion 2009;24:373-80.

17. Shander A, Hofmann A, Ozawa S, Theusinger OM, Gombotz $\mathrm{H}$, Spahn DR. Activity-based costs of blood transfusions in surgical patients at four hospitals. Transfusion 2010;50:753-65.

18. Budak AB, McCusker K, Gunaydin S. A structured blood conservation program in pediatric cardiac surgery. Eur Rev Med Pharmacol Sci 2017;21:1074-9.

19. Budak AB, McCusker K, Gunaydin S. A Cardiopulmonary Bypass Based Blood Management Strategy in Adult Cardiac Surgery. Heart Surg Forum 2017;20:E195-8.

20. Lafçı A , Gökçınar D , Dağ O , Günertem E , Günaydın S. The effect of "patient blood management" training on the number of red blood cell transfusions in patients undergoing cardiac surgery: a 5-year retrospective study. Turkish Journal of Clinics and Laboratory 2019;10:98-103.

21. Gunaydin S. The evolution of patient blood management programs in cardiac surgery: what is the ultimate frontier? Presented at the 57th AmSECT International Conference; March 8-10, 2019; Nashville, TN, USA.

22. Gunaydin S, McCusker K. Protective efficacy of minimally invasive techniques on patient blood management programs in aortic valve surgery. Presented at the 19th ISMICS Annual
Scientific Meeting; May 29-Jun 1, 2019; New York, USA.

23. Spahn DR, Schoenrath F, Spahn GH, Seifert B, Stein P, Theusinger OM, et al. Effect of ultra-short-term treatment of patients with iron deficiency or anaemia undergoing cardiac surgery: a prospective randomised trial. Lancet 2019;393:2201-12.

24. Vlot EA, Verwijmeren L, van de Garde EMW, Kloppenburg GTL, van Dongen EPA, Noordzij PG. Intra-operative red blood cell transfusion and mortality after cardiac surgery. BMC Anesthesiol 2019;19:65.

25. National blood and blood components preparation, use and quality assurance guideline-2016. Available at: https:// www.kanver.org/Upload/Dosya/ulusal_kan_rehberi.pdf [Accessed: March 03, 2019].

26. National hemovigilance guideline-2016. Available at: https:// sbu.saglik.gov.tr/Ekutuphane/Yayin/528 [Accessed: March 03, 2019].

27. Froessler B, Olsen K, Parker B, Robinson KL. Room for improvement: audit results of perioperative red cell transfusion practice at an Australian university teaching hospital. Anaesth Intensive Care 2009;37:852.

28. Meybohm P, Richards T, Isbister J, Hofmann A, Shander A, Goodnough LT, et al. Patient Blood Management Bundles to Facilitate Implementation. Transfus Med Rev 2017;31:62-71.

29. Spahn DR, Muñoz M, Klein AA, Levy JH, Zacharowski K. Patient Blood Management: Effectiveness and Future Potential. Anesthesiology 2020;133:212-22. 